\title{
Występowanie roślin obcego pochodzenia na terenach tramwajowych konurbacji śląskiej (południowa Polska)
}

\author{
Alina Urbisz i PaUlina WoźnicA
}

\begin{abstract}
Urbisz, A. AND WoźnICA, P. 2020. Occurrence of alien plant species along streetcar lines in the Silesian conurbation (S Poland). Fragmenta Floristica et Geobotanica Polonica 27(2): 473-493. Kraków. e-ISSN 2449-8890, ISSN 1640-629X.

ABSTRACT: This paper presents a list of 99 alien plant species recorded in 2014-2019 along streetcar lines in the Silesian conurbation. For each species, data are given for geographical and historical classification, frequency of occurrence in biotopes, and the sites where the plants were recorded. Categories of invasiveness were determined for invasive taxa.
\end{abstract}

KeY words: alien plants, invasive plant species, Poland, Silesia, tram track

A. Urbisz, Instytut Biologii, Biotechnologii i Ochrony Środowiska, Wydział Nauk Przyrodniczych, Uniwersytet Ślaski w Katowicach, ul. Jagiellońska 28, 40-032 Katowice, Polska; e-mail: alina. urbisz@us.edu.pl

P. Woźnica, ul. A. Śliwki 14/17, 41-208 Sosnowiec, Polska; e-mail: paulinawoznica@wp.pl

\section{WSTĘP}

Specyficznym typem siedliska, występującym w wielu miastach, są torowiska tramwajowe (SUDNIK-WÓJCIKOWSKA \& GALERA 2005). Transport tramwajowy jest chętnie wybierany przez mieszkańców ze względu na swój „,ekologiczny” charakter a także, dzięki wyłączeniu torowisk z jezdni, uniezależnienie od drogowych utrudnień komunikacyjnych, co zdecydowanie ułatwia podróżowanie w zatłoczonych miastach (STOECK 2012; KLERA \& BACIECZKO 2013). Szata roślinna towarzysząca torowiskom tramwajowym jest bardzo słabo poznana. Opublikowano niewiele prac uwzględniających florę i roślinność torowisk tramwajowych (SudNiK-WóJCIKOWSKa \& Galera 2005; 2011; KLERA 2008; KleRA \& BACIECZKo 2013). Wykształcająca się na torowiskach tramwajowych flora oraz roślinność pełni różnorodne funkcje. Przede wszystkim stanowi określony walor estetyczny, co często decyduje o zagospodarowaniu tych obszarów, np. w kierunku tzw. zielonych torowisk (GIEDYCH i in. 2012; WAGNER i in. 2013), wpływa ona także na mikroklimat siedlisk (WAGNER i in. 2013). Jednocześnie linie/torowiska tramwajowe mogą stanowić drogę migracji dla wielu gatunków, w tym roślin obcego pochodzenia, prowadząc do ich liniowego rozprzestrzeniania się.

Głównym celem niniejszej pracy jest przedstawienie zróżnicowania flory antropofitów torowisk tramwajowych konurbacji śląskiej oraz ich preferencji w odniesieniu do wyróżnionych biotopów. 


\section{MATERIAE I METODY}

Badania prowadzono na terenie konurbacji śląskiej, położonej w centralnej i wschodniej części województwa śląskiego (południowa Polska). Jest to obszar liczący kilkanaście ośrodków miejskich skupionych wokół Katowic - stolicy województwa (BUDNER 2008). W skład konurbacji śląskiej wchodzi 14 miast na prawach powiatu: Katowice, Bytom, Chorzów, Świętochłowice, Gliwice, Zabrze, Ruda Śląska, Piekary Śląskie, Siemianowice Śląskie, Tychy, Mysłowice, Sosnowiec, Dąbrowa Górnicza oraz Jaworzno. Ponadto 10 miast (w tym m.in. Będzin i Czeladź) zaklasyfikowano jako obszar śródmiejski (Plan ZaGospodaroWania PrZestrzennego WoJewódzTw ŚląSKIEGo 2004).

Pod względem podziału fizyczno-geograficznego konurbacja śląska znajduje się w obrębie Wyżyny Śląskiej (KONDRACKI 1998; SOLON i in. 2018). Makroregion ten charakteryzuje się klimatem umiarkowanie ciepłym o optymalnym uwilgotnieniu (ZIERNICKA-WOJTASZEK \& ZAWORA 2009). Przeważają wiatry zachodnie, chociaż na klimat wpływ mają zarówno masy powietrza oceanicznego z zachodu, jak i kontynentalne ze wschodu. Średnia roczna temperatura w 2015 r. wyniosła $9,7^{\circ} \mathrm{C}$, a roczna suma opadów nie przekroczyła $600 \mathrm{~mm}$ (UstRNUL i in. 2015). Tereny zurbanizowane charakteryzują się jednak lokalnymi topoklimatami, będącymi wynikiem intensywnej działalności antropogenicznej.

Sieć tramwajowa oraz niezbędna do jej utrzymania infrastruktura techniczna, rozmieszczona jest w 13 miastach: Katowicach, Bytomiu, Chorzowie, Świętochłowicach, Gliwicach, Zabrzu, Rudzie Śląskiej, Siemianowicach Śląskich, Mysłowicach, Sosnowcu, Dąbrowie Górniczej, Czeladzi oraz Będzinie (WOJTASZEK 2015).

Specyficzną cechą konurbacji śląskiej jest to, że transport tramwajowy łączy ze sobą kilka miast. Łączna długość torowisk na terenie konurbacji śląskiej wynosi 338,6 km toru pojedynczego (km. t. p.), z czego 29 km t. p. stanowią tory na terenie zajezdni Rejonów i Zakładu Usługowo Remontowego. Na trasach linii tramwajowych występują odcinki dwutorowe o długości 239,3 km t. p, jednotorowe o długości $58,7 \mathrm{~km} \mathrm{t}$. p. oraz 11,6 km t. p. torów stanowiących pętle tramwajowe (TrAmWAJE ŚLĄSKIE S.A. 2018). Najważniejszym elementem infrastruktury tramwajowej są torowiska definiowane, jako: „element trasy tramwajowej stanowiący pas drogi szynowej przeznaczonej do ruchu tramwajów" (OLEKSIEWICZ \& KRAŚKIEWICZ 2013). Ze względu na usytuowanie dróg szynowych można wyróżnić:

- torowiska tramwajowe wydzielone z jezdni (w pasie drogowym, ale nie pokrywającym się z drogą kołową, przeznaczone wyłącznie dla ruchu tramwajowego i często oddzielone wyniesionym ponad powierzchnię jezdni separatorem);

- torowiska wspólne z jezdnią (inaczej zabudowane w jezdni; w pasie drogowym, przeznaczone dla ruchu tramwajowego, kołowego i pieszego);

- torowiska niezależne (położone poza szlakiem komunikacyjnym, zwykle także poza obszarami zagospodarowanymi i przeznaczone wyłącznie do ruchu tramwajów) (CZAUDERna 2004; OLEKSIEWICZ \& KRAŚKIEWICZ 2013).

W skład infrastruktury tramwajowej wchodzą, poza drogami szynowymi, także: przystanki i zajezdnie tramwajowe, sieć i podstacje trakcyjne oraz punkty regulatorskie (TrAmWAJE ŚLĄSKIE S.A. 2018).

Tereny związane $\mathrm{z}$ transportem tramwajowym są zróżnicowane pod względem intensywności użytkowania, zagospodarowania i występującego podłoża. Z tego względu badania terenowe wzdłuż linii tramwajowych prowadzono w obrębie wyróżnionych trzech biotopów ${ }^{1}$, w skład których wchodziły: ścisłe torowiska tramwajowe (T), przytorza tramwajowe (P) oraz tereny infrastrukturalne (I). Ścisłe torowiska obejmowały tereny między szynami oraz pas o szerokości pół metra od skrajnej szyny, a w przypadku torowisk podwójnych, także obszary między torami (Ryc. 1). Charakteryzują się one intensywnym oddziaływaniem ruchu tramwajowego, silną insolacją i zazwyczaj słabo wykształconą pokrywą glebową, pokrywającą warstwę tłucznia (SUDNIK-WóJCIKOWSKA \& GALERA 2005; KLERA 2008). Przytorza stanowiły pasy biegnące liniowo wzdłuż torowisk, których odległość od zewnętrznej szyny wynosiła od 0,5 do 2,5 metra. Tereny infrastruktury to, zazwyczaj 2,5-5 metrowe, obszary okalające przytorza w takich miejscach, jak: wysepki komunikacyjne, pętle tramwajowe, zajezdnie oraz przystanki i ich bezpośrednie otoczenie.

\footnotetext{
1 Biotop - środowisko abiotyczne zmienione przez biocenozę; czyli miejsce życia organizmów danego gatunku wraz ze wszystkimi czynnikami fizycznymi i biotycznymi (WeINER 2003).
} 


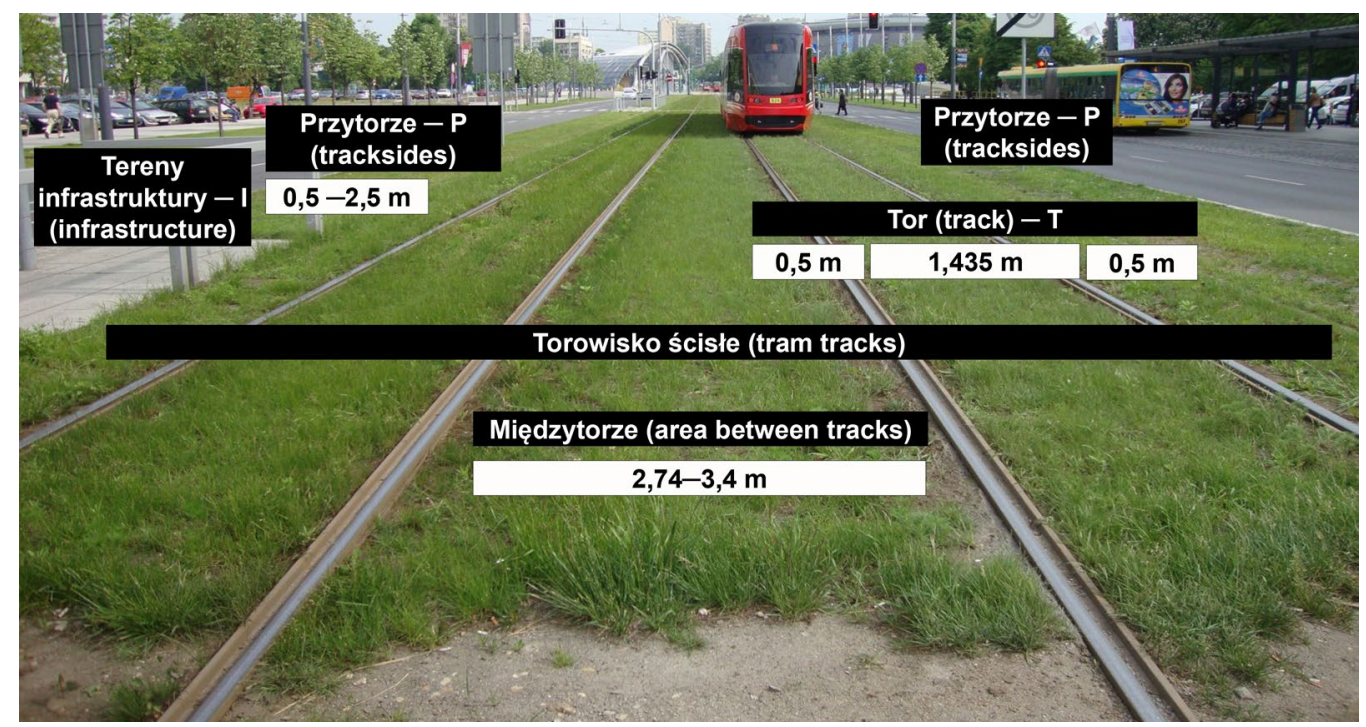

Ryc. 1. Rozmieszczenie biotopów w których prowadzono badania na przykładzie odcinka dwutorowego

Fig. 1. Distribution of explored biotopes - an example of a double-track transect

Badania terenowe przeprowadzono w latach 2014-2019. Spisy florystyczne, z uwzględnieniem wszystkich trzech wyróżnionych biotopów, wykonano przede wszystkim na torowiskach wyłączonych z jezdni, gdyż tylko tam stwierdzono występowanie roślin. W przypadku przytorzy spisów dokonywano maksymalnie do 2,5 m, jeśli zachowana była ciagłość charakteru przytorza. W przypadku oddzielenia terenu np. rzędem nasadzonego żywopłotu, barierką lub krawężnikiem, za którymi znajdowała się zieleń urządzona - park, skwer lub inne siedlisko (np. las) spisu flory dokonywano wyłącznie do bariery. Nie spisywano gatunków zieleni urządzonej nasadzonej na terenie przytorzy (np. gatunków drzew w alejach, ozdobnych krzewinek w klombach) z wyjątkiem osobników wnikających spontanicznie do objętych badaniami biotopów.

Łącznie badaniami objęto 122 kilometry torowisk (pojedynczych i/lub podwójnych, przy czym torowiska podwójne traktowano jako jeden odcinek). Nie brano pod uwagę torowisk nieczynnych, całkowicie wyłączonych już z ruchu oraz zabudowanych w jezdni. W obrębie całej konurbacji wyznaczono 122 jednokilometrowe odcinki, będące podstawowymi jednostkami badawczymi (Ryc. 2; Tab. 1). Spisy przeprowadzono co najmniej dwukrotnie w trakcie sezonu wegetacyjnego (w każdym odcinku badawczym) - wczesnym i późnym latem.

Dla odnotowanych gatunków sporządzono listę florystyczną. Wykaz gatunków przedstawiono w porządku alfabetycznym uwzględniając wszystkie gatunki obcego pochodzenia, łącznie z roślinami zdziczałymi z upraw. Dla każdego taksonu podano następujące informacje:

1. Nazwę łacińską gatunku (według MiRKA i in. 2002).

2. Grupę geograficzno-historyczną, zgodnie z podziałem i kryteriami przyjętymi w pracy ToKARSKA-GuzIK i in. (2012). Wyróżniono: archeofity - dawni przybysze (sprzed 1500 r. n.e.); kenofity - nowi przybysze (po 1500 r. n.e.); diafity - gatunki niezadomowione trwale.

3. Biotop w którym gatunek występował. Przyjęto dla nich następujące oznaczenia: T - torowisko ścisłe; P - przytorze; I - infrastruktura.

4. Częstość występowania gatunków w obrębie każdego biotopu - oparta na występowaniu gatunków w badanych odcinkach. Przyjęto następujące przedziały: gatunek pospolity - odnotowany w 93-122 odcinkach (powyżej 75\% badanych odcinków), gatunek częsty - odnotowany w 62-92 odcinkach (50-75\% odcinków), gatunek rzadki - odnotowany w 32 do 61 odcinkach (25-50\% odcinków), gatunek bardzo rzadki (b. rzadki) - odnotowany od 7 do 31 odcinków (5-25\% odcinków), gatunek sporadyczny - odnotowany na mniej niż 6 odcinkach torowisk (poniżej 5\% badanych odcinków). 
Tabela 1. Wykaz odcinków badawczych wraz z przebiegiem ich tras na badanym terenie

Table 1. List of research sections along with their routes in the studied area

\begin{tabular}{|c|c|}
\hline $\begin{array}{l}\text { Numer } \\
\text { odcinka } \\
\text { (Section } \\
\text { number) }\end{array}$ & $\begin{array}{l}\text { Przebieg trasy/odcinka } \\
\text { (Course of the route/section) }\end{array}$ \\
\hline 1 & Czeladź Pętla - Czeladź Wodociągi \\
\hline 2 & Czeladź: Wodociaggi - Piaski Centrum handlowe M1 \\
\hline 3 & Czeladź Piaski: Centrum handlowe M1 - Będzin: Skrzyżowanie Nerka \\
\hline 4 & Będzin: Skrzyżowanie Nerka - Będzin Zajezdnia \\
\hline 5 & Będzin: Skrzyżowanie Nerka - Będzin Kościół \\
\hline 6 & Będzin Kościół - Dąbrowa Górnicza (DG) Pętla Sobieskiego \\
\hline 7 & Będzin: Nerka - Będzin Krasickiego \\
\hline 8 & Będzin Krasickiego - Będzin Słowackiego \\
\hline 9 & Będzin: Słowackiego - Będzin Wiadukt \\
\hline 10 & Sosnowiec: Będzińska Wiadukt - Sosnowiec Kościół św. Tomasza \\
\hline 11 & Sosnowiec: Kościół św. Tomasza - Sosnowiec Sielec \\
\hline 12 & Sosnowiec: Sielec - Sosnowiec ul. 3-go Maja Dworzec Sosnowiec Główny \\
\hline 13 & Dąbrowa Górnicza DG: Pętla Tworzeń Huta - DG Stal-Złom \\
\hline 14 & DG: Stal-Złom - DG Gołonóg Instal \\
\hline 15 & DG: Gołonóg Instal - DG Oś. Kasprzaka \\
\hline 16 & DG: Oś. Kasprzaka Pawilony - DG Piłsudskiego 46 (Gołonóg Centrum) \\
\hline 17 & DG: Piłsudskiego 46 (Gołonóg Centrum) - DG McDonald's Gołonóg Damel \\
\hline 18 & DG: McDonald's Gołonóg Damel - DG Szczęsny-Zjawiony Reden \\
\hline 19 & DG: Szczęsny-Zjawiony Reden - DG Rondo Centrum \\
\hline 20 & DG: Rondo Centrum - Urząd Pracy Pętla Sobieskiego, DG Pętla (I) \\
\hline 21 & Sosnowiec, Milowice: Park Logistyczny S86 - Podjazdowa Milowice Zakłady Mięsne Duda \\
\hline 22 & Sosnowiec, Milowice: Podjazdowa Milowice Zakłady Mięsne Duda - Pętla \\
\hline 23 & Sosnowiec Dańdówka: Skrzyżowanie - Sosnowiec Kolonia Pstrowskiego \\
\hline 24 & Sosnowiec Dańdówka: Kolonia Pstrowskiego - Sosnowiec Park Malczewskiej \\
\hline 25 & Sosnowiec Dańdówka: Park Malczewskiej - Sosnowiec Cmentarz \\
\hline 26 & Sosnowiec Dańdówka: Cmentarz - Sosnowiec KWK Kazimierz-Juliusz \\
\hline 27 & Sosnowiec Dańdówka: KWK Kazimierz-Juliusz - Sosnowiec Pętla \\
\hline 28 & Sosnowiec Andersa: Skrzyżowanie - Sosnowiec Andersa Szkoła \\
\hline 29 & Sosnowiec Andersa: Szkoła - Sosnowiec Rondo Ludwik \\
\hline 30 & Sosnowiec Wojska Polskiego: Cmentarz - Watta \\
\hline 31 & Sosnowiec Wojska Polskiego: Watta - Dańdówka Skrzyżowanie \\
\hline 32 & Sosnowiec Wojska Polskiego: Cmentarz - Modrzejów \\
\hline 33 & Sosnowiec Modrzejów - Mysłowice Dw. PKP \\
\hline 34 & Sosnowiec 1 maja: Sąd - Sosnowiec Rondo Ludwik \\
\hline 35 & Sosnowiec Narutowicza: Rondo Ludwik - Sosnowiec „Zamek” \\
\hline 36 & Sosnowiec Narutowicza :,Zamek” - Sosnowiec Staszica \\
\hline 37 & Świętochłowice: Lipiny Mijanka - Chropaczów Szkoła Barlickiego \\
\hline 38 & Świętochłowice: Chropaczów Lampego - Łagiewniki Targowisko ul. Łagiewnicka \\
\hline 39 & $\begin{array}{l}\text { Świętochłowice, ul. Bytomska: Łagiewniki Targowisko - Świętochłowice Chropaczów Osiedle } \\
\text { na Wzgórzu Ślęzan }\end{array}$ \\
\hline 40 & $\begin{array}{l}\text { Świętochłowice, ul. Bytomska: Chropaczów Osiedle na Wzgórzu (Ślęzan) - Świętochłowice Piaśniki } \\
\text { Skrzyżowanie }\end{array}$ \\
\hline
\end{tabular}


Tabela 1. Kontynuacja - Table 1. Continued

\begin{tabular}{|c|c|}
\hline $\begin{array}{l}\text { Numer } \\
\text { odcinka } \\
\text { (Section } \\
\text { number) }\end{array}$ & $\begin{array}{l}\text { Przebieg trasy/odcinka } \\
\text { (Course of the route/section) }\end{array}$ \\
\hline 41 & Świętochłowice, ul. Bytomska: Piaśniki Skrzyżowanie - Świętochłowice Kościół \\
\hline 42 & Świętochłowice, Mijanka ul. Katowicka Wojska Polskiego - Świętochłowice Komenda Policji \\
\hline 43 & Świętochłowice Zgoda Skrzyżowanie - Zgoda Ceramiczna Ruda Śląska \\
\hline 44 & Ruda Śląska, Katowicka: Zgoda Ceramiczna Ruda Śląska - Ruda Śląska Bykowina Mijanka \\
\hline 45 & Ruda Śląska, Katowicka: Bykowina Mijanka - Ruda Śląska Rondo Odrodzenia \\
\hline 46 & Świętochłowice, Chorzowska: Chebzie Pawła - Świętochłowice Lipiny Targowisko \\
\hline 47 & Świętochłowice, Chorzowska: Lipiny Targ - Świętochłowice Bukowego \\
\hline 48 & Świętochłowice, Chorzowska: Bukowego - Świętochłowice Piaśniki Skrzyżowanie ul. Bytomska \\
\hline 49 & Świętochłowice: Piaśniki Skrzyżowanie - Chorzów Wodociągi \\
\hline 50 & Bytom, Zabrzańska: Centrum Bytom Zamłynie - Bytom Szombierki Kolonia Górnicza Intermarche \\
\hline 51 & $\begin{array}{l}\text { Bytom, Zabrzańska: Intermarche Bytom Szombierki Kolonia Górnicza - Ruda Śl. Szombierki Frycza } \\
\text { Modrzewskiego }\end{array}$ \\
\hline 52 & Ruda Śl., Godula: Szombierki Frycza Modrzewskiego - Ruda Śl. Kopalnia Karol Osiedle Paryż \\
\hline 53 & Ruda Śl., Godula: Osiedle Paryż Kopalnia Karol - Ruda Śl. Godula Plac Niepodległości Rencistów \\
\hline 54 & Ruda Śl., Godula: Ruda Śl. Godula Plac Niepodległości - Ruda Śl. Chebzie Pawła \\
\hline 55 & Ruda Śl., Zabrzańska: Poremba Bielszowicka - Zabrze \\
\hline 56 & Ruda Śl., Zabrzańska: Poremba Bielszowicka - Ruda Śl. Parking TIR \\
\hline 57 & Ruda Śl., Zabrzańska: Parking TIR - Ruda Śl. Chebzie \\
\hline 58 & Ruda Śl., Zabrzańska: Chebzie Pętla - Ruda Śl. Niedurnego (Kaufhaus) \\
\hline 59 & Ruda Śl., Niedurnego: Parking - Ruda Śl. Most \\
\hline 60 & Ruda Śl., Niedurnego: Most - Ruda Śl. Rondo Odrodzenia (Wirek Kopalnia Pokój) \\
\hline 61 & Bytom, ul. Wrocławska: Pętla - Bytom Didura Bytom Kąpielisko \\
\hline 62 & Bytom, ul. Wrocławska: Didura Bytom Kąpielisko - Bytom Skwer - Batorego \\
\hline 63 & Bytom, ul. Wrocławska: Skwer Wrocławska - Bytom Piłkarska \\
\hline 64 & Bytom, Bytom Urząd Miasta - Bytom Batorego (Centrum) \\
\hline 65 & Bytom: Piłkarska - Strzelców Bytomskich Cmentarz Dąbrowa Miejska Węglowa \\
\hline 66 & $\begin{array}{l}\text { Bytom: Strzelców Bytomskich Dąbrowa Miejska Węglowa Cmentarz - Dąbrowa Miejska Centrum Han- } \\
\text { dlowe Objazdowa }\end{array}$ \\
\hline 67 & Bytom: Objazdowa (Dąbrowa Miejska Centrum Handlowe) - Stroszek Plac Żeromskiego Sikorskiego \\
\hline 68 & Bytom: Stroszek Plac Żeromskiego Sikorskiego - Stroszek Osiedle Lidl \\
\hline 69 & Bytom, Łagiewnicka Łagiewniki Targowisko (Skrzyżowanie) - Łagiewniki Szyby Rycerskie \\
\hline 70 & Bytom, Łagiewnicka: Łagiewniki Szyby Rycerskie - Bytom Łagiewnicka \\
\hline 71 & Bytom, Zabrzańska: Szombierki Kościół - Szombierki Elektrownia \\
\hline 72 & Bytom, Zabrzańska: Konstytucji Bobrek Ratusz - Szombierki Elektrownia \\
\hline 73 & Zabrze, Wolności: Zaborze Wolności- Zaborze Lompy \\
\hline 74 & Zabrze, Wolności: Zaborze Lompy - Zaborze Elektrociepłownia \\
\hline 75 & Zabrze, Wolności: Zaborze Elektrociepłownia - Sienkiewicza \\
\hline 76 & Zabrze, Wolności: Sienkiewicza - Zabrze Lutra \\
\hline 77 & Zabrze, Wolności: Karola Miarki - Damrota \\
\hline 78 & Zabrze, Wolności: Damrota - Słowackiego \\
\hline 79 & Zabrze, Wolności: Słowackiego - Kondratowicza \\
\hline 80 & Zabrze, Kondratowicza - Gliwice Zajezdnia \\
\hline
\end{tabular}


Tabela 1. Kontynuacja - Table 1. Continued

\begin{tabular}{|c|c|}
\hline $\begin{array}{l}\text { Numer } \\
\text { odcinka } \\
\text { (Section } \\
\text { number) }\end{array}$ & $\begin{array}{c}\text { Przebieg trasy/odcinka } \\
\text { (Course of the route/section) }\end{array}$ \\
\hline 81 & Zabrze, Makoszowska: Pętla - Koksownia \\
\hline 82 & Zabrze, Makoszowska: Koksownia - Rondo \\
\hline 83 & Zabrze, Tarnopolska: Mikulczyce Plac Kroczka - Mikulczyce Pętla \\
\hline 84 & Zabrze, Mikulczycka: Lidl - Wiadukt Kolejowy \\
\hline 85 & Zabrze, Mikulczycka: Wiadukt Kolejowy - Mostostal \\
\hline 86 & Zabrze, Mikulczycka: Mostostal - Religi \\
\hline 87 & Zabrze, Bytomska: Religi - Hagera \\
\hline 88 & Zabrze, Bytomska: Hagera - Biskupice Młyńska \\
\hline 89 & Zabrze, Bytomska: Ziemska - Trębacka \\
\hline 90 & Zabrze, Bytomska: polna droga staw - Ziemska \\
\hline 91 & Zabrze, Bytomska: Konstytucji (Bobrek oś. Pod Brzozami) - polna droga staw \\
\hline 92 & Bytom, Konstytucji: Kościół - Bobrek Szkoła - Bobrek Osiedle pod Brzozami \\
\hline 93 & Bytom, Bobrek: Osiedle pod Brzozami - Ruda Kuźnica Rudzka \\
\hline 94 & Siemianowice Śląskie: Plac Skargi (Pętla) - Grabowa \\
\hline 95 & Chorzów: Teatr Rozrywki - AKS \\
\hline 96 & Chorzów: Chorzów Nowa (Statoil) - Teatr Rozrywki \\
\hline 97 & Chorzów: granica miasta (Łagiewniki Zajezdnia Pętla) - Chorzów Nowa (Statoil) \\
\hline 98 & Bytom, Chorzowska: Łagiewniki Zajezdnia - Łagiewniki Cmentarz \\
\hline 99 & Bytom: Łagiewniki Cmentarz - Bytom Park Mickiewicza \\
\hline 100 & Bytom, Chorzowska: Park Mickiewicza -Teatr Tańca Rozbark \\
\hline 101 & Katowice: Szopienice Chemiczna - Mysłowice: Świerczyny \\
\hline 102 & Katowice, Kościuszki: Stadion - ALMA \\
\hline 103 & Katowice, Kościuszki: ALMA - Zieleń Miejska \\
\hline 104 & Katowice, Kościuszki: Zieleń Miejska - Pętla \\
\hline 105 & Katowice, Szopienice: Wiosny Ludów - Pętla \\
\hline 106 & Katowice, Szopienice: Giełda - Pętla \\
\hline 107 & Katowice, Szopienice: Obrońców Westerplatte Poczta - Burowiec \\
\hline 108 & Katowice, Szopienice: Obrońców Westerplatte do Zawodzia \\
\hline 109 & Katowice, Chorzowska: Ściegiennego Skrzyżowanie - Silesia City Center (SCC) \\
\hline 110 & Katowice, Chorzowska: SCC - Dąb Kościół \\
\hline 111 & Katowice, Chorzowska: Dąb Kościół - Chorzowska Śląski Ogród Zoologiczny \\
\hline 112 & Katowice, Chorzowska: Śląski Ogród Zoologiczny - Stadion Pętla \\
\hline 113 & Katowice, Zawodzie: 1 maja - ul. Obrońców Westerplatte do ul. Roździeńskiego \\
\hline 114 & Katowice, Zawodzie: Pętla Zawodzie - Akademia Ekonomiczna \\
\hline 115 & Katowice: Załęże - Załęże Katowice Dom Kultury \\
\hline 116 & Katowice: Załęże Dom Kultury - Katowice Dwór \\
\hline 117 & Katowice, Korfantego: Plac Alfreda - Wełnowiec Kościół \\
\hline 118 & Katowice, Korfantego: Wełnowiec Kościół - Pętla Słoneczna \\
\hline 119 & Sosnowiec: Os. Zamkowa - Sosnowiec Osiedle Środula \\
\hline 120 & Sosnowiec: Osiedle Środula - Pętla \\
\hline 121 & Bytom: ul. Sikorskiego - Zajezdnia \\
\hline 122 & Chorzów: Al. Bojowników o Wolności i Demokrację (Dom Działkowca) - Chorzów Racławicka \\
\hline
\end{tabular}




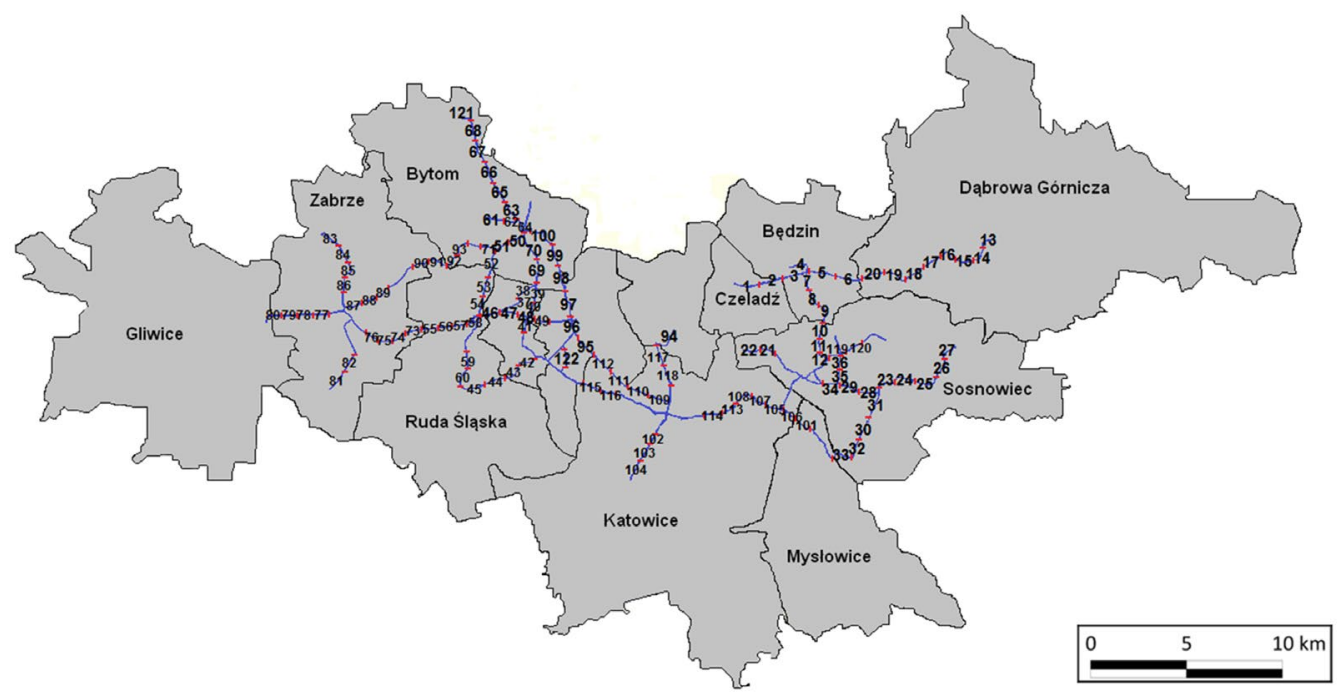

Ryc. 2. Podział torowisk tramwajowych konurbacji śląskiej na 122 jednokilometrowe odcinki badawcze

Fig. 2. Division of tram tracks of the Silesian conurbation into 122 1-km research sections

5. Wykaz odcinków, w których odnotowano gatunek. Podano liczbę oraz numer(y) odcinka(ów), w którym gatunek występował (Tab. 1).

6. Szacunkową liczbę osobników i/lub sposób występowania (np. pojedynczo, w skupieniach, łanowo).

7. Jako uwagę (Uwaga:) dla gatunków uznanych za inwazyjne podano kategorię inwazyjności (TOKARSKA-GUZIK i in. 2012): gatunek inwazyjny w skali kraju, inwazyjny regionalnie lub inwazyjny lokalnie.

Niniejsza praca prezentuje część wyników uzyskanych w trakcie 5-letnich badań, dotyczących flory gatunków obcego pochodzenia na tego typu siedliskach. Miały one znacznie szerszy zakres i dotyczyły zróżnicowania szaty roślinnej terenów tramwajowych. Analiza ta zostanie przedstawiona w odrębnej publikacji.

\section{WYKAZ GATUNKÓW}

Acer negundo - Kenofit. T (częsty), P (b. rzadki), I (sporadyczny).

80 odcinków: 1-4, 6-8, 10-21, 23-28, 31-33, 35-39, 41-45, 48, 50-51, 54-56, 58, 60-61, 64-65, 67, 69-70, 73-75, 78-80, 84-87, 93-99, 101, 105-108, 111-118; zazwyczaj pojedyncze kilkuletnie osobniki, siewki jednoroczne lokalnie na torowiskach ścisłych tworzyły gęsty nalot.

Uwaga: Gatunek inwazyjny w skali kraju.

Aesculus hippocastanum - Kenofit. T (sporadyczny), P (sporadyczny).

7 odcinków: 24, 30, 37, 52, 56, 69, 105; pojedyncze siewki.

Aethusa cynapium - Archeofit. T (sporadyczny).

2 odcinki: 52,78 ; pojedyncze okazy.

Agrostemma githago - Archeofit. P (sporadycznie).

1 odcinek: 27; pojedynczy okaz.

Ailanthus altissima - Kenofit. T (sporadyczny), $\mathbf{P}$ (sporadyczny).

7 odcinków: 4-5, 12, 26, 108, 116, 122; pojedyncze jednoroczne lub kilkuletnie siewki.

Uwaga: Gatunek regionalnie inwazyjny. 
Amaranthus retroflexus - Kenofit. T (rzadki), P (b. rzadki), I (sporadyczny).

55 odcinków: 1-4, 7-11, 17-18, 20, 23-25, 28, 30-32, 40, 43-45, 50-51, 54-55, 59, 65, 69-74, 76-80, 82, 84-88, 95-97, 104, 111-112, 115, 117, 122; lokalnie na torowiskach ścisłych w gęstych skupieniach. Uwaga: Gatunek inwazyjny w skali kraju.

Anagallis arvensis - Archeofit. T (b. rzadki), P (sporadyczny).

2 odcinki: 111, 117; pojedyncze osobniki.

Antirrhinum majus - Diafit. T (sporadyczny).

1 odcinek: 8; pojedynczy okaz (uciekinier z pobliskiego ogrodu).

Aquilegia $\times$ hybrida - Diafit. P (sporadyczny).

1 odcinek: 103; pojedynczy okaz (uciekinier z pobliskiego ogrodu).

Armoracia rusticana - Archeofit. T (sporadyczny), P (sporadyczny), I (sporadyczny).

7 odcinków: 29, 42, 103-104, 110-112; pojedyncze osobniki.

Artemisia absinthium - Archeofit. T (sporadyczny), P (sporadyczny), I (sporadyczny).

9 odcinków: 4, 31, 39, 80, 114-115, 117-118, 121; pojedyncze osobniki.

Bromus sterilis - Archeofit. T (sporadyczny).

2 odcinki: 51,78; niewielkie skupienia zwykle wokół słupów trakcyjnych.

Bromus tectorum - Archeofit. P (sporadyczny).

2 odcinki: 41,106; lokalnie w gęstych skupieniach szczególnie wokół słupów trakcyjnych.

Capsella bursa-pastoris - Archeofit. T (b. rzadki), P (b. rzadki), I (sporadyczny).

37 odcinków: 3-4, 11, 13-14, 24-25, 27, 39, 41, 44, 46-47, 51, 63, 68-69, 73, 78, 80-81, 84, 88, 94, 102, 104-106, 110-117, 121-122; zazwyczaj pojedyncze okazy, lokalnie w gęstych skupieniach.

Centaurea cyanus - Archeofit. P (sporadyczny).

2 odcinki: 56, 74; pojedyncze okazy.

Cerastium tomentosum - Diafit. T (sporadyczny), $\mathbf{P}$ (sporadyczny).

3 odcinki: 95, 109, 119; lokalnie w gęstych skupieniach.

Chamomilla suaveolens - Kenofit. T (b. rzadki), P (b. rzadki), I (sporadyczny).

25 odcinków: 4, 11, 17, 20-22, 28, 30-31, 51, 78, 80-81, 96, 102-105, 109-110, 113-114, 117, 121-122; pojedynczo lub w niewielkich skupieniach.

Chenopodium hybridum - Archeofit. P (sporadyczny).

1 odcinek: 43; pojedynczy osobnik.

Clematis vitalba - Kenofit . T (sporadyczny), P (sporadyczny).

4 odcinki: $24,51,75,115$; pojedyncze okazy.

Uwaga: Gatunek regionalnie inwazyjny.

Conyza canadensis - Kenofit. T (pospolity), P (częsty), I (rzadki).

118 odcinków: 1-28, 30-37, 39-51, 53-57, 59-122; lokalnie w gęstych skupieniach

Uwaga: Gatunek inwazyjny w skali kraju.

Datura stramonium - Archeofit. P (sporadyczny).

1 odcinek: $111 ; 3$ okazy.

Descurainia sophia - Archeofit. T (sporadyczny).

2 odcinki: 43,113; pojedyncze okazy.

Deutzia scabra - Diafit. P (sporadyczny).

1 odcinek: 116; pojedynczy okaz. 
Digitaria ischaemum - Archeofit. T (rzadki), P (rzadki), I (sporadyczny).

38 odcinków: 3-5, 9, 11, 13, 19, 21-26, 28, 32-34, 36, 55, 59, 65, 69, 73-74, 76, 80-82, 84, 87, 95, 109, 117; lokalnie w gęstych skupieniach.

Digitaria sanguinalis - Archeofit. T (rzadki), P (b. rzadki), I (sporadyczny).

43 odcinki: 3, 10-11, 19, 21-26, 28, 30-35, 42-43, 45, 50, 59-60, 71, 73-78, 80-81, 84-87, 89, 94-95, 103-104, 115, 117; lokalnie w gęstych skupieniach.

Diplotaxis muralis - Kenofit. T (rzadki), P (b. rzadki), I (sporadyczny).

63 odcinki: 3-11, 13-20, 22-27, 29, 34-35, 38-39, 44-45, 47, 56, 60, 73-76, 78-80, 84, 86, 88, 90-91, 95-96, 98, 102-108, 111, 114-118, 121-122; zazwyczaj pojedyncze okazy.

Uwaga: Gatunek regionalnie inwazyjny.

Echinochloa crus-galli - Archeofit. T (rzadki), P (b. rzadki), I (b. rzadki).

69 odcinków: 1, 3-5, 7, 9-16, 20-25, 27-32, 34-36, 41, 43-44, 49-50, 56, 58-59, 63-65, 67-70, 73, 75-79, 81-82, 86-91, 93, 96, 99, 103-104, 106, 108, 111-113, 116-118; zazwyczaj pojedyncze okazy, lokalnie w gęstych skupieniach.

Uwaga: Gatunek inwazyjny w skali kraju.

Echinocystis lobata - Kenofit. T (sporadyczny), P (sporadyczny).

2 odcinki: 26,39; pojedyncze okazy.

Uwaga: Gatunek inwazyjny w skali kraju.

Epilobium adenocaulon - Kenofit. T (sporadyczny), P (sporadyczny).

2 odcinki: 102,105; pojedyncze okazy.

Uwaga: Gatunek inwazyjny w skali kraju.

Eragrostis minor - Kenofit. T (rzadki), P (b. rzadki), I (rzadki)

60 odcinków: 4, 19-25, 31-32, 34, 44-45, 55-60, 64-65, 68-69, 71, 73-82, 84-87, 89-90, 92, 94-95, 99, 103-104, 106-118, 121; lokalnie w gęstych skupieniach.

Uwaga: na badanym terenie gatunek należałoby uznać za inwazyjny lokalnie.

Erigeron annuus - Kenofit. T (b. rzadki), P (b. rzadki), I (sporadyczny).

42 odcinki: $8,13,25,30-31,36,41-43,45,55,61-63,65-68,71,73-75,80-82,86-90,93,95$, 100-101, 104, 106, 111-113, 116, 122; pojedynczo lub w większych skupieniach.

Uwaga: Gatunek inwazyjny w skali kraju.

Euphorbia helioscopia - Archeofit. T (b. rzadki), P (b. rzadki), I (sporadyczny).

20 odcinków: 13, 16-17, 21, 24, 37-38, 44, 55, 69, 78-79, 81, 85-86, 95, 97-98, 111-112; pojedyncze okazy.

Euphorbia maculata - Kenofit. T (sporadyczny), I (sporadyczny).

2 odcinki: 105, 110; kilkadziesiąt okazów (Ryc. 3).

Uwaga: na badanym terenie kilka okazów tego gatunku stwierdzono po raz pierwszy, między płytkami chodnika, w 2018 r. na przystanku tramwajowym „Szopienice Pętla”, przy ulicy Wiosny Ludów w Katowicach Szopienicach (URBISZ 2019). Kolejne, nowe stanowisko tej rośliny odnotowano w 2019 r. na torowisku ścisłym oraz między płytkami chodnika na przystanku tramwajowym „Dąb - Huta Baildon” w centrum Katowic, co świadczy o tym, że gatunek ten rozprzestrzenia się wzdłuż torowisk tramwajowych.

Euphorbia peplus - Archeofit. T (rzadki), P (b. rzadki).

49 odcinków: $6,11,15-19,22-23,28-29,33,36,38-39,44-45,48,51-55,63-64,66,71-76,78-79$, 81-85, 87-91, 93-94, 97, 102, 117; zazwyczaj pojedyncze okazy lub w niewielkich skupieniach.

Fallopia convolvulus - Archeofit. T (rzadki), $\mathbf{P}$ (b. rzadki).

50 odcinków: 1, 3-7, 9-10, 14-16, 18, 21-22, 25-26, 29, 32-33, 35, 39, 43-45, 51-53, 58, 64-65, $67,69-71,73-74,76,78,82,86,88,90,93,97-99,102-103,117,122$; zazwyczaj w niewielkich skupieniach. 


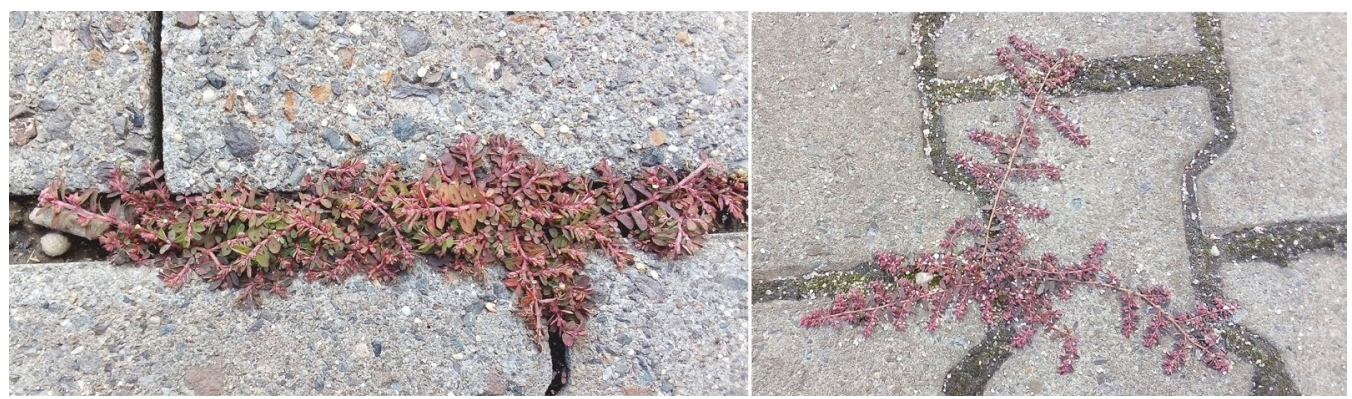

Ryc. 3. Euphorbia maculata na przystanku tramwajowym Katowice Huta Baildon (21.09.2019 r.; fot. Al. Urbisz)

Fig. 3. Euphorbia maculata at the Katowice Huta Baildon tram stop (21.09.2019; photo by Al. Urbisz)

Fraxinus pennsylvanica - Kenofit. T (sporadyczny), P (b. rzadki), I (sporadyczny).

11 odcinków: 56-57, 64, 72, 89, 95, 101, 115-117, 120; pojedynczo, jednoroczne lub kilkuletnie siewki.

Uwaga: Gatunek inwazyjny w skali kraju.

Galeopsis angustifolia - Kenofit. T (sporadyczny).

1 odcinek: 109; liczne osobniki na powierzchni ok. $20 \mathrm{~m}^{2}$.

Galinsoga ciliata - Kenofit. T (rzadki), P (b. rzadki), I (sporadyczny).

56 odcinków: 11, 14, 19, 21-26, 28, 31, 33-36, 39, 41-45, 51-52, 55, 59-60, 62-64, 75-76, 79-86, 89-90, 93, 95, 97, 100, 103-104, 106, 112-118, 121-122; pojedynczo lub w niewielkich skupieniach.

Uwaga: Gatunek inwazyjny w skali kraju.

Galinsoga parviflora - Kenofit. T (częsty), P (b. rzadki), I (b. rzadki).

97 odcinków: 1-2, 4-7, 11-12, 14-25, 27-32, 34-35, 38, 41-46, 49-56, 58-60, 62-64, 66-69, 73-74, 76-80, 82-90, 93-98, 102, 104, 106, 109, 111-113, 115, 117-118, 121-122; pojedynczo lub w niewielkich skupieniach.

Uwaga: Gatunek inwazyjny w skali kraju.

Geranium pusillum - Archeofit. T (b. rzadki), P (b. rzadki).

27 odcinków: 4, 7-8, 12, 16, 23-27, 32-33, 41, 45, 50, 52, 63, 66-67, 73-74, 79, 85, 100, 104, 109-110; pojedynczo lub w niewielkich skupieniach.

Helianthus tuberosus - Kenofit. P (sporadyczny).

1 odcinek: 84; kilkanaście osobników.

Uwaga: Gatunek inwazyjny w skali kraju.

Hordeum murinum - Archeofit. T (sporadyczny), P (sporadyczny), I (sporadyczny).

12 odcinków: 4, 43, 47, 51, 73, 75-76, 78, 80, 109, 111, 121; w gęstych skupieniach szczególnie wokół słupów trakcyjnych.

Uwaga: Gatunek regionalnie inwazyjny.

Impatiens glandulifera - Kenofit. P (sporadyczny).

1 odcinek: 85; kilka osobników.

Uwaga: Gatunek inwazyjny w skali kraju.

Impatiens parviflora - Kenofit. T (b. rzadki), P (b. rzadki), I (sporadyczny).

23 odcinki: $15,21,25,33,39-40,45,51-52,57,59,67,72,80-83,90-91,93-94,101,106$; pojedyncze lub w niewielkich skupieniach szczególnie w miejscach częściowo zacienionych.

Uwaga: Gatunek inwazyjny w skali kraju. 
Juglans regia - Kenofit. T (sporadyczny), P (b. rzadki), I (sporadyczny).

24 odcinki: 4, 13, 19, 24, 41, 45, 56, 60, 63, 78, 80, 82, 84-86, 89-90, 95, 97, 100, 102, 104, 115-116; pojedyncze jednoroczne lub kilkuletnie siewki.

Uwaga: Gatunek regionalnie inwazyjny.

Juncus tenuis - Kenofit. I (sporadyczny).

1 odcinek: 111, pojedyncze kępy między płytkami chodnika na przystanku.

Uwaga: Gatunek inwazyjny w skali kraju.

Lactuca serriola - Archeofit. T (częsty), P (rzadki), I (sporadyczny).

76 odcinków: $1-2,4-8,10,12-15,18-20,22-23,25,27,30-31,33,35-37,39,41,44-47,49-51$, 55-62, 64-75, 77-80, 85, 87, 89-90, 93, 95-99, 102-105, 107-114, 119-122; pojedynczo lub w niewielkich skupieniach.

Lamium album - Archeofit. T (sporadyczny), $\mathbf{P}$ (b. rzadki).

9 odcinków: 4, 15, 24, 26, 41, 51, 97, 114-115; pojedyncze okazy.

Lamium amplexicaule - Archeofit. T (sporadyczny).

1 odcinek: 73; kilkanaście osobników.

Lamium purpureum - Archeofit. T (b. rzadki), P (b. rzadki), I (sporadyczny).

21 odcinków: $15,17,26,31,41,43,45,52,58-60,73,79,83,85,87-88,91,94,100$, 103; pojedynczo lub w niewielkich skupieniach.

Lepidium campestre - Archeofit. T (sporadyczny).

2 odcinki: 73,78; lokalnie w dość licznych skupieniach.

Lepidium densiflorum - Kenofit. T (sporadyczny), $\mathbf{P}$ (sporadyczny).

4 odcinki: 51, 76, 96-97; pojedynczo lub w niewielkich skupieniach.

Lepidium ruderale - Archeofit. T (rzadki), P (b. rzadki), I (sporadyczny).

49 odcinków: 3-4, 6, 17-18, 23, 27, 31, 37-41, 43-45, 47, 50-51, 54-56, 60-61, 64, 69, 72-74, 78-79, 82, 85-89, 102-105, 109, 111, 113-115, 117, 121-122; zazwyczaj pojedynczo, lokalnie w dość licznych skupieniach.

Lolium multiflorum - Kenofit. T (b. rzadki), P (b. rzadki), I (sporadyczny).

28 odcinków: $2,14,21,28-29,31,35,39,48,50,52,57,59,64,66-67,69-70,80,87,96,99,104$, 106, 111-112, 114, 121; lokalnie, szczególnie na terenach przytorzy, w dość licznych skupieniach.

Uwaga: Gatunek regionalnie inwazyjny.

Malus domestica - Kenofit. T (sporadyczny), P (sporadyczny), I (sporadyczny)

3 odcinki: 102, 104, 106; pojedyncze kilkuletnie siewki.

Malva neglecta - Archeofit. T (sporadyczny), P (sporadyczny).

2 odcinki: 102,118; pojedyncze osobniki.

Malva sylvestris - Archeofit. T (sporadyczny), P (sporadyczny).

7 odcinków: 1, 3, 13, 25, 44-45, 101; pojedyncze osobniki.

Matricaria maritima subsp. inodora - Archeofit. T (b. rzadki), P (b. rzadki), I (sporadyczny).

43 odcinki: 4, 6, 7, 11-13, 15, 17, 20-21, 25-26, 30-31, 33, 41-46, 49, 53, 55, 57-58, 60-61, 64, 68, $72-73,79-81,83,95,100,110,112,114-115,121$; zazwyczaj w pojedynczych kępach.

Medicago sativa - Kenofit. T (rzadki), P (rzadki), I (b. rzadki).

61 odcinków: 1, 3-10, 12-13, 16-20, 22-24, 32-35, 42, 44-45, 48, 56, 60-61, 64-68, 72, 75, 78, 81, 83-84, 86, 89, 99, 101, 104-111, 113-115, 117-120; zazwyczaj w pojedynczych kępach, lokalnie, szczególnie na przytorzach, w licznych skupieniach. 
Medicago $\times$ varia - Kenofit. T (b. rzadki), P (b. rzadki), I (sporadyczny).

36 odcinków: 1-10, 13, 17-20, 22-25, 35, 66, 80, 84, 99, 104, 108-111, 114-116, 118-120, 122; zazwyczaj pojedyncze kępy.

Melandrium album - Archeofit. T (rzadki), P (częsty), I (b. rzadki).

98 odcinków: 1, 3-4, 6-24, 26-28, 30-32, 34-37, 39, 41-60, 62-63, 65-66, 68-73, 75, 78-81, 84-85, 88, 90, 94, 96-97, 99-107, 109-122; pojedyncze osobniki, lokalnie szczególnie na przytorzach w niewielkich skupieniach.

Microbiota decussata - Diafit. P (sporadyczny).,

1 odcinek: 98; pojedynczy osobnik.

Myosotis arvensis - Archeofit. T (sporadyczny), $\mathbf{P}$ (sporadyczny).

2 odcinki: 47,73; w niewielkich skupieniach.

Oxalis stricta - Kenofit. T (rzadki), $\mathbf{P}$ (b. rzadki), I (b. rzadki).

33 odcinki: 16, 21-22, 30-33, 37, 39, 42, 44-45, 53, 55, 59-60, 63-64, 69, 74-76, 78-79, 82-83, 85-89, 93, 98, 100, 103-104, 122; zazwyczaj w niewielkich skupieniach, lokalnie licznie.

Uwaga: Gatunek inwazyjny w skali kraju.

Padus serotina - Kenofit. P (sporadyczny).

1 odcinek: 102; pojedynczy kilkuletni osobnik.

Uwaga: Gatunek inwazyjny w skali kraju.

Papaver argemone - Archeofit. P (sporadyczny).

1 odcinek: 110; kilkanaście osobników.

Papaver rhoeas - Archeofit. T (b. rzadki), P (b. rzadki).

23 odcinki: $2-8,15,23,26-27,34,39,46-47,68,74-75,80,102,109,112,120$; pojedynczo lub w skupieniach po kilkanaście osobników.

Parthenocissus inserta - Kenofit. T (b. rzadki), P (b. rzadki), I (sporadyczny).

38 odcinków: 2-4, 6-7, 9, 11, 16, 20, 24, 26, 32-33, 37, 39, 41-43, 45, 56, 63, 65, 75, 85, 88-91, 93, $95,97,100,103,108,110,114,117,122$; pojedynczo lub w niewielkich skupieniach

Uwaga: Gatunek regionalnie inwazyjny.

Parthenocissus quinquefolia - Kenofit. P (sporadyczny).

1 odcinek: 32; pojedynczy osobnik.

Pastinaca sativa - Archeofit. T (częsty), P (pospolity), I (b. rzadki).

114 odcinków: 1-51, 53, 55-76, 78-104, 106, 108-109, 111-118, 120-122; na torowiskach ścisłych pojedynczo, na przytorzach często w skupieniach.

Populus $\times$ canadensis - Kenofit. T (sporadyczny), P (sporadyczny), I (sporadyczny).

7 odcinków: 98, 106, 108, 114-116, 121; pojedyncze kilkuletnie siewki.

Potentilla intermedia - Kenofit. T (sporadyczny).

2 odcinki: 78,105; pojedyncze osobniki.

Prunus cerasifera - Kenofit. P (sporadyczny).

1 odcinek: 96; pojedynczy kilkuletni osobnik.

Quercus rubra - Kenofit. T (b. rzadki), $\mathbf{P}$ (b. rzadki), I (sporadyczny).

20 odcinków: 22 , 26, 32, 37, 41, 54, 62-63, 65, 82, 94, 96, 100, 106, 113, 115-118, 122; pojedyncze jednoroczne lub kilkuletnie siewki.

Uwaga: Gatunek inwazyjny w skali kraju.

Raphanus raphanistrum - Archeofit. T (rzadki), P (b. rzadki), I (sporadyczny).

37 odcinków: 4-12, 15-19, 28-29, 34-37, 39-40, 43-45, 47, 60, 63, 81, 94-99, 113, 119; pojedynczo lub w niewielkich skupieniach. 
Reynoutria japonica - Kenofit. T (b. rzadki), P (rzadki), I (sporadyczny).

67 odcinków: 4, 7, 9-10, 13, 15-17, 19, 21, 23, 25, 28, 31-34, 39-45, 49-51, 54-56, 58, 60-63, 66, 69-71, 73-74, 85, 87, 89-91, 94-97, 100-101, 103-104, 106-107, 109-117, 120, 122; na terenach tramwajowych, szczególnie na przytorzach, występuje często w postaci pojedynczych kęp.

Uwaga: Gatunek inwazyjny w skali kraju.

Rhus typhina - Kenofit. T (sporadyczny), P (sporadyczny).

9 odcinków: 1, 3-4, 13, 23, 61, 71, 84, 94; pojedyncze okazy wnikają, zwykle wegetatywnie, z pobliskiego otoczenia.

Uwaga: Gatunek regionalnie inwazyjny.

Robinia pseudoacacia - Kenofit. T (rzadki), P (rzadki), I (sporadyczny).

50 odcinków: 4, 13, 21-22, 24-25, 27, 31-33, 36-44, 47, 50, 53-57, 59-62, 64-65, 67, 69-71, 74, $76,79-80,82,85,87-92,98,101-105,107-108,113-115,117-118,122$; pojedyncze jednoroczne lub kilkuletnie siewki, lokalnie w licznych skupieniach.

Rosa rugosa - Kenofit. T (sporadyczny), P (sporadyczny), I (sporadyczny).

11 odcinków: 1, 38, 61, 63, 65, 71, 82, 87, 103, 120-121; pojedyncze osobniki.

Uwaga: Gatunek regionalnie inwazyjny.

Rudbeckia hirta - Kenofit. P (sporadyczny).

1 odcinek: 32; pojedynczy osobnik, uciekinier z pobliskiego ogrodu.

Sedum album - Kenofit. T (sporadyczny), P (sporadyczny).

2 odcinki: 110,112; w skupieniach po kilkadziesiąt osobników na torowiskach ścisłych i przytorzach (Ryc. 4).

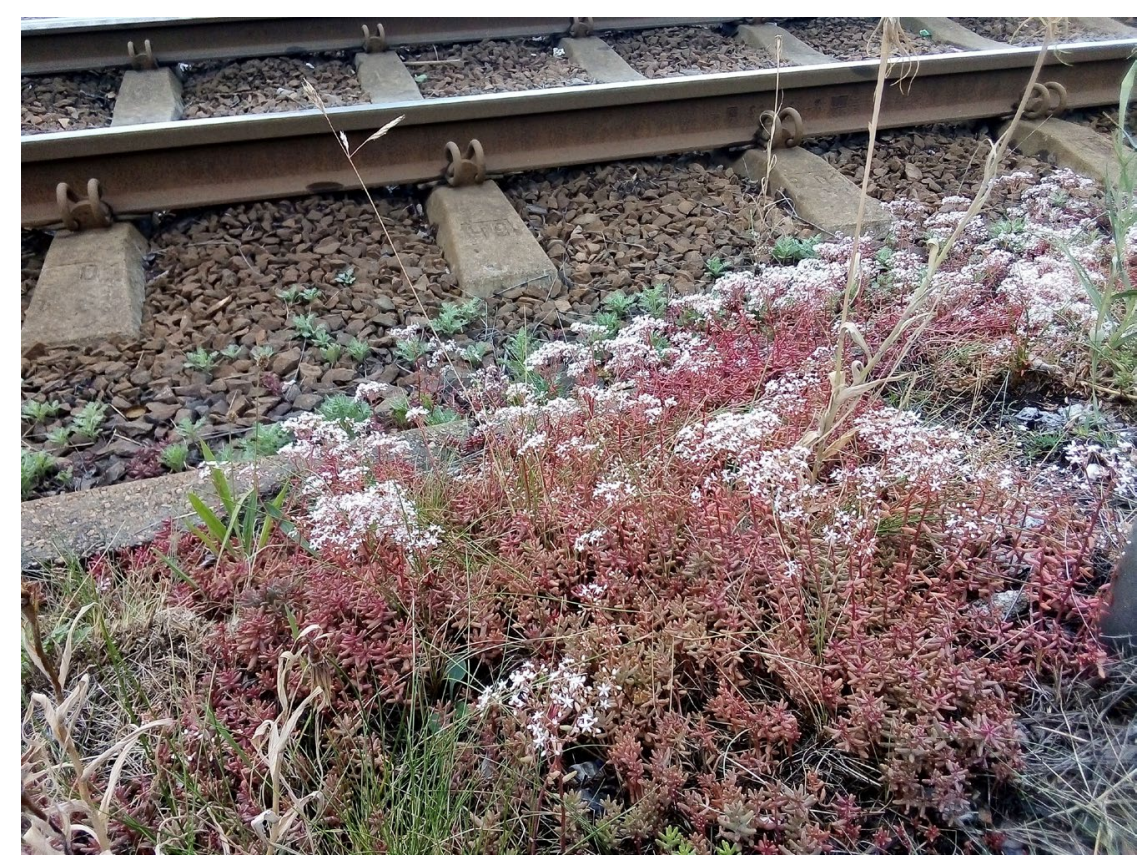

Ryc. 4. Sedum album na przytorzu oraz torowisku ścisłym w pobliżu przystanku Silesia City Center - Katowice (20.06.2019 r.; fot. Al. Urbisz)

Fig. 4. Sedum album on the trackside and track near the Silesia City Center stop - Katowice 20.06.2019; photo by Al. Urbisz) 
Senecio vernalis - Kenofit. T (b. rzadki), $\mathbf{P}$ (b. rzadki), I (b. rzadki).

32 odcinki: 1, 4-5, 7-9, 17-19, 25, 28, 33-34, 36, 41, 44, 51, 56, 58, 61-62, 74, 80, 95-96, 99-100, 104-105, 109, 114, 116; pojedynczo lub w niewielkich skupieniach.

Senecio vulgaris - Archeofit. T (rzadki), P (b. rzadki), I (sporadyczny).

78 odcinków: 1-15, 17-19, 21-22, 28-29, 31, 37, 41, 43-45, 50-51, 53, 55-57, 59-60, 64, 69-71, 73-76, 78-80, 82-88, 90-91, 94-95, 98, 101-104, 106-118, 120, 122; pojedynczo lub w niewielkich skupieniach.

Setaria pumila - Archeofit. T (rzadki), P (b. rzadki), I (sporadyczny).

59 odcinków: 2-5, 8-9, 11, 13-15, 17-21, 24, 32, 36, 39-40, 43-44, 50-51, 55-56, 58, 62-64, 67-70, 72-73, 75-76, 78-90, 92-93, 97, 101, 110, 114, 121-122; pojedynczo lub w niewielkich skupieniach.

Uwaga: Gatunek inwazyjny w skali kraju.

Setaria verticillata - Archeofit. I (b. rzadki).

1 odcinek: 115; pojedyncza kępa przy przystanku, prawdopodobnie uciekinier z pobliskich ogródków działkowych.

Setaria viridis - Archeofit. T (częsty), $\mathbf{P}$ (b. rzadki), I (b. rzadki).

82 odcinki: 1, 3-6, 8-11, 13-18, 20-26, 28-29, 34-37, 39, 41, 47, 49-51, 55, 57, 59-65, 67-68, 70-71, 73-92, 95-96, 98, 102-104, 109-110, 112-115, 117, 120-121; pojedynczo lub w niewielkich skupieniach.

Uwaga: Gatunek inwazyjny w skali kraju.

Sisymbrium loeselii - Kenofit. T (sporadyczny), $\mathbf{P}$ (sporadyczny).

3 odcinki: 105-107; pojedyncze osobniki.

Sisymbrium officinale - Archeofit. T (b. rzadki), P (b. rzadki).

33 odcinki: 3-4, 13, 16-17, 32-34, 39, 41, 44-45, 51-52, 57-59, 62, 78-79, 81, 84, 94, 97-100, 102-103, 106, 115-116, 122; pojedynczo lub w niewielkich skupieniach (szczególnie na przytorzach).

Solanum nigrum - Archeofit. T (b. rzadki), P (sporadyczny), I (sporadyczny).

15 odcinków: 11, 21, 23-24, 30-31, 43-45, 70, 98, 103, 110, 117, 122; zazwyczaj pojedyncze osobniki lub w niewielkich skupieniach.

Solidago canadensis - Kenofit. T (rzadki), P (częsty), I (b. rzadki).

76 odcinków: 1-4, 7-13, 20, 22, 24-26, 29-32, 38-39, 41-45, 50-52, 54-66, 71-74, 77-85, 87-88, 90-108, 111-118, 121-122; pojedynczo lub w skupieniach po kilkadziesiąt osobników (szczególnie na przytorzach).

Uwaga: Gatunek inwazyjny w skali kraju.

Solidago gigantea - Kenofit. T (sporadyczny), P (b. rzadki), I (sporadyczny).

13 odcinków: 31, 38-39, 52-53, 56, 63, 80, 82, 105, 107, 113, 116; pojedyncze osobniki

Uwaga: Gatunek inwazyjny w skali kraju.

Sonchus asper - Archeofit. T (rzadki), P (b. rzadki), I (sporadyczny).

45 odcinków: 1-7, 9, 12-18, 21-23, 28, 31, 34, 36, 43, 56, 61, 69, 72-73, 76, 78-79, 81-82, 84, 88, 94, 102-105, 108, 111, 116-117, 121; zazwyczaj pojedyncze osobniki.

Sonchus oleraceus - Archeofit. T (pospolity), P (częsty), I (b. rzadki).

110 odcinków: 1-23, 25, 28-51, 53-90, 92-99, 101-122; pojedynczo lub w skupieniach po kilkadziesiąt osobników (szczególnie na przytorzach).

Symphoricarpos albus - Kenofit. P (b. rzadki), I (sporadyczny).

12 odcinków: 4, 21, 24, 39, 44, 63, 72, 83-84, 95, 115, 117; pojedyncze kępy.

Urtica urens - Archeofit. P (sporadyczny).

2 odcinki: 40,106; kilkanaście osobników.

Veronica persica - Kenofit. T (sporadyczny).

1 odcinek: 73; kilkanaście osobników.

Uwaga: Gatunek inwazyjny w skali kraju. 
Vicia dasycarpa - Kenofit. T (b. rzadki), P (sporadyczny).

10 odcinków: $6,13-15,17-19,84,117-118$; pojedyncze kępy.

Vicia hirsuta - Archeofit. I (sporadyczny).

1 odcinek: 113; niewielki płat.

Viola arvensis - Archeofit. T (rzadki), $\mathbf{P}$ (b. rzadki).

53 odcinki: $1-4,6-10,13-17,22-23,26,32-33,41,43-44,47,50-51,53,55,57,63,65-68,73,76$, $78-79,81-82,85,94,96,99-100,102-103,106,108-109,112,116-117,121$; pojedynczo lub w skupieniach po kilkadziesiąt osobników (szczególnie na torowiskach ścisłych).

\section{DYSKUSJA I PODSUMOWANIE}

Torowiska tramwajowe, przy zachowaniu nawet niewielkiej warstwy gleby, stanowią miejsce rozwoju roślin wkraczających spontanicznie z otaczających je siedlisk miejskich. W związku z liniowym charakterem mogą stanowić drogę migracji dla wielu gatunków, które poprzez ruchy powietrza mają możliwość szybkiego rozprzestrzeniania się (PRIEMUS \& ZonNeVeld 2003; HANSEN \& Clevengerg 2005; WiŁKOMIRSKI i in. 2012; RutKovsKA i in. 2013).

$\mathrm{Na}$ terenie torowisk tramwajowych konurbacji śląskiej odnotowano 99 gatunków roślin obcego pochodzenia, spośród których 45 to archeofity, 49 kenofity a 5 to diafity. Analizując rozmieszczenie badanych antropofitów w wyróżnionych 122 odcinkach badawczych (Ryc. 5), stwierdzono, że liczba odnotowanych w nich gatunków wynosi od 8 do 40. Wysoką koncentracją gatunków (> 30), charakteryzuje się zaledwie 7 odcinków (4, 44, 45, 73, 78, 115 i 117). Są one położone na terenie miast: Zabrze, Ruda Śląska, Katowice i Będzin, zazwyczaj na ich peryferiach. Torowiska te charakteryzują się wykształconą pokrywą glebową i przebiegają w otoczeniu terenów niezabudowanych, przemysłowych, pól lub nieużytków. Tory/linie tramwajowe biegnące na obrzeżach są mniej eksploatowane w porównaniu z położonymi w centrum lub będącymi częścią węzłów komunikacyjnych. Większość z nich od dawna nie było remontowanych, w związku z tym charakteryzują się one brakiem lub mniejszą warstwą tłucznia oraz obecnością grubszej pokrywy glebowej, która stwarza stabilne i dogodne warunki do rozwoju flory w ścisłych torowiskach. Występująca w ich otoczeniu roślinność może stanowić źródło diaspor gatunków, które mogą zasiedlać tereny torowisk.

Najmniej gatunków antropofitów (<11), stwierdzono w 6 odcinkach (46, 48, 49, 77, 92 i 119), zlokalizowanych w Zabrzu, Bytomiu, Świętochłowicach, Chorzowie i Sosnowcu. Jest to związane $\mathrm{z}$ ich położeniem $\mathrm{w}$ centralnej części miast oraz słabo wykształconej warstwie gleby, co często jest spowodowane prowadzonymi w ostatnich latach pracami remontowymi. W miejscach silniejszego wpływu działalności człowieka torowiska biegną zwykle wzdłuż dróg samochodowych, nie tylko w pasie oddzielającym jezdnię, ale często po jednej z jej stron, co powoduje, że graniczą one bezpośrednio z otoczeniem przydroży.

We florze badanych torowisk 23 gatunki posiadaja status inwazyjnych w skali kraju (3 archeofity i 20 kenofitów), 9 to rośliny inwazyjne regionalnie a 1 to takson lokalnie inwazyjny. Spośród gatunków inwazyjnych na badanym terenie najczęściej występowały: Acer negundo (siewki i kilkuletnie osobniki), Conyza canadensis, Diplotaxis muralis, 


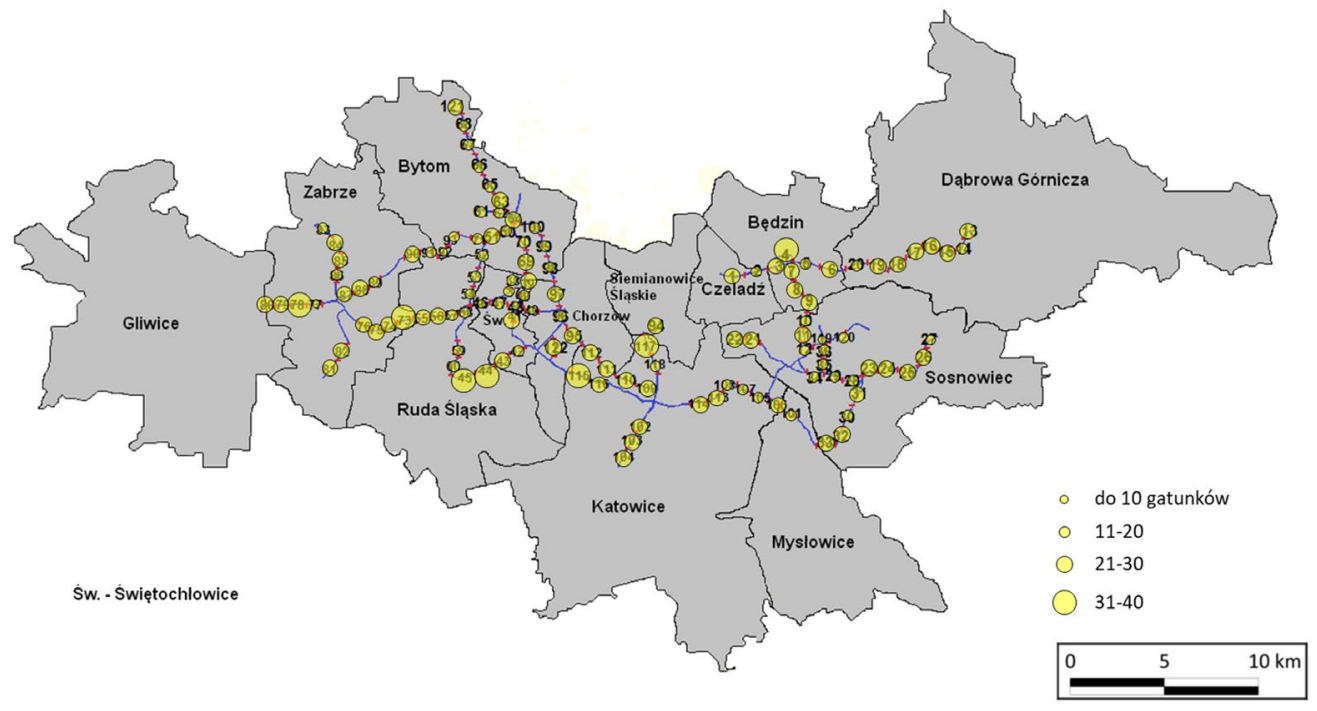

Ryc. 5. Koncentracja stanowisk antropofitów odnotowanych w wyróżnionych odcinkach badawczych

Fig. 5. Concentration of localities of anthropophyte species occurring in the distinguished research sections

Echinochloa crus-galli, Galinsoga parviflora, Reynoutria japonica, Setaria viridis i Solidago canadensis. Najrzadziej natomiast notowano Clematis vitalba (4 odcinki), Echinocystis lobata (2), Epilobium adenocaulon (2) oraz w jednym odcinku: Helianthus tuberosus, Impatiens glandulifera, Juncus tenuis, Padus serotina i Veronica persica.

Antropofity, związane z torowiskami tramwajowymi konurbacji śląskiej, zazwyczaj nie wykazują szczególnych preferencji w stosunku do zajmowanego biotopu. Większość z nich występowało zarówno na torowiskach ścisłych, przytorzach jak i infrastrukturze. Najwięcej gatunków odnotowano na przytorzach (86) oraz torowiskach ścisłych (81), a najmniej na terenach infrastruktury (51), co może być związane z relatywnie małą powierzchnią tego biotopu. Analizując występowanie gatunków w poszczególnych typach biotopów stwierdzono, że wyłącznie na terenach:

- torowisk ścisłych wystąpiło 9 gatunków: Aethusa cynapium, Antirrhinum majus, Bromus sterilis, Descurainia sophia, Galeopsis angustifolia, Lamium amplexicaule, Lepidium campestre, Potentilla intermedia i Veronica persica.

- przytorzy - 14 gatunków: Agrostemma githago, Aquilegia $\times$ hybrida, Bromus tectorum, Centaurea cyanus, Chenopodium hybridum, Datura stramonium, Deutzia scabra, Helianthus tuberosus, Impatiens glandulifera, Microbiota decussata, Padus serotina, Papaver argemone, Rudbeckia hirta i Urtica urens.

- infrastruktury - 3 gatunki: Juncus tenuis, Setaria verticillata i Vicia hirsuta.

Większość antropofitów występowała w więcej niż jednym typie biotopu. Najmniej gatunków odnotowano wyłącznie na terenach przytorzy i infrastruktury - 1 gatunek (Symphoricarpos albus) oraz torowisk ścisłych i infrastruktury - 1 gatunek (Euphorbia maculata). W biotopach obejmujących torowiska ścisłe i przytorza stwierdzono 25 gatunków, natomiast we wszystkich badanych biotopach łącznie występowało 46 taksonów (Ryc. 6). 
We wszystkich analizowanych biotopach przeważają gatunki bardzo rzadkie, natomiast najmniej liczne są pospolite i częste (Ryc. 7). Najwięcej gatunków archeofitów, jak i kenofitów stwierdzono na przytorzach $(\mathrm{P})$ oraz torowiskach ścisłych $(\mathrm{T})$. W wyróżnionych biotopach, wśród kenofitów, odnotowano większe udziały gatunków sporadycznych (Ryc. 8).

Tereny tramwajowe, na obszarach miast, mogą być korytarzami migracji dla roślin obcego pochodzenia, w tym gatunków inwazyjnych. Na badanym terenie są to: np. Acer negundo, Ailanthus altissima, Fraxinus pennsylvanica, Solidago canadensis lub Reynoutria japonica. $\mathrm{Z}$ sąsiadujących z torowiskami siedlisk rośliny te mogą wnikać poprzez przytorze na torowiska ścisłe. Należy też zwrócić uwagę, że gatunki, które już wkroczą na torowiska ścisłe, mogą rozprzestrzeniać się na obszarze miast, co potwierdzają również badania prowadzone np. na terenach wąskotorowej kolei miejskiej Brunszwiku (BRANDES 2005).

W ostatnich latach coraz częściej obserwowane jest zwiększanie się liczby oraz częstości występowania gatunków termofilnych w miastach (SUDNIK-WóJCIKOWSKA 1998; 2002). Są to zazwyczaj rośliny przywiązane do najcieplejszych, centralnych części miast, gdzie obserwujemy zjawisko tzw. „miejskiej wyspy cieplnej”. O jej wykształceniu się decydują m.in. ocieplający wpływ zabudowy oraz liczne w miastach dodatkowe źródła emisji ciepła. Biorąc pod uwagę specyfikę terenów tramwajowych, ten typ siedliska można byłoby włączyć do siedlisk charakterystycznych dla „wyspy cieplnej”. Spośród wskazywanych przez SuDNIK-WóJCIKOwSKą (2002), najbardziej termofilnych gatunków, na terenie torowisk tramwajowych konurbacji śląskiej odnotowano: Bromus sterilis, Diplotaxis muralis, Hordeum murinum oraz Eragrostis minor.

$\mathrm{Na}$ badanym obszarze stwierdzono występowanie Sedum album oraz bardzo rzadkiego na terenie Polski kenofita - Euphorbia maculata. Miejsca występowania tych gatunków należałoby monitorować, gdyż działalność człowieka (przejazdy tramwajów, wydeptywanie, oczyszczanie chodników, modernizacja i opryskiwanie torowisk) może mieć wpływ zarówno na ich rozprzestrzenianie się wzdłuż linii tramwajowych, jak i na zanik obecnie istniejących stanowisk.

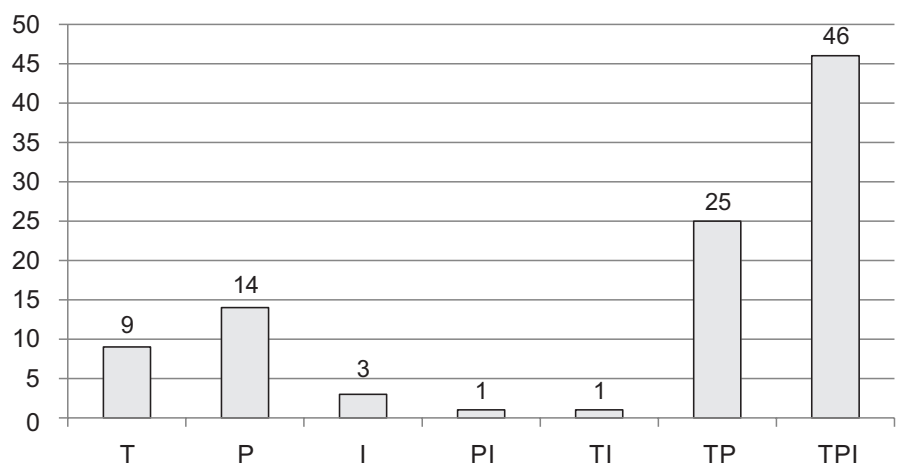

Ryc. 6. Liczba gatunków występujących wyłącznie w wyróżnionych biotopach oraz ich grupach: T - torowiska ścisłe, $\mathrm{P}$ - przytorza, I - tereny infrastruktury, PI - przytorza i tereny infrastruktury, TI - torowiska ścisłe i tereny infrastruktury, TP - torowiska ścisłe i przytorza, TPI - torowiska ścisłe, przytorza i tereny infrastruktury

Fig. 6. Number of species found exclusively in the distinguished biotopes and their groups: $\mathrm{T}-\operatorname{tram} \operatorname{tracks}, \mathrm{P}-\operatorname{track}-$ sides, I - infrastructure, PI - tracksides and infrastructure, TI - tram tracks and infrastructure, TP - tram tracks and tracksides, TPI - tram tracks, tracksides and infrastructure 


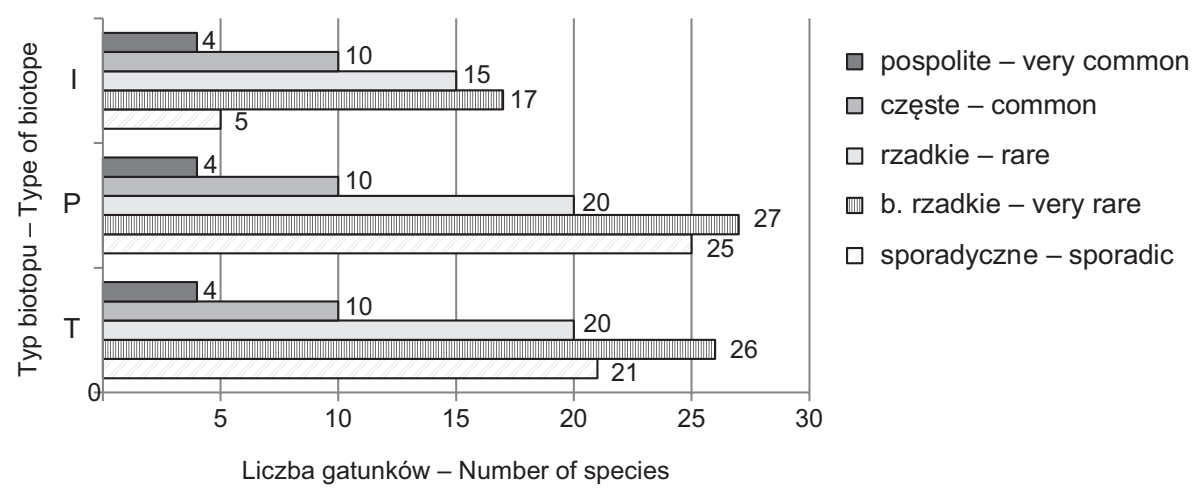

Ryc. 7. Liczba antropofitów w wyróżnionych biotopach z uwzględnieniem częstości ich występowania: T - torowiska ścisłe, P - przytorza, I - tereny infrastruktury

Fig. 7. Number of anthropophytes in selected biotopes, taking into account their frequency of occurrence: $\mathrm{T}-\operatorname{tram}$ tracks, $\mathrm{P}$ - tracksides, I - infrastructure

A

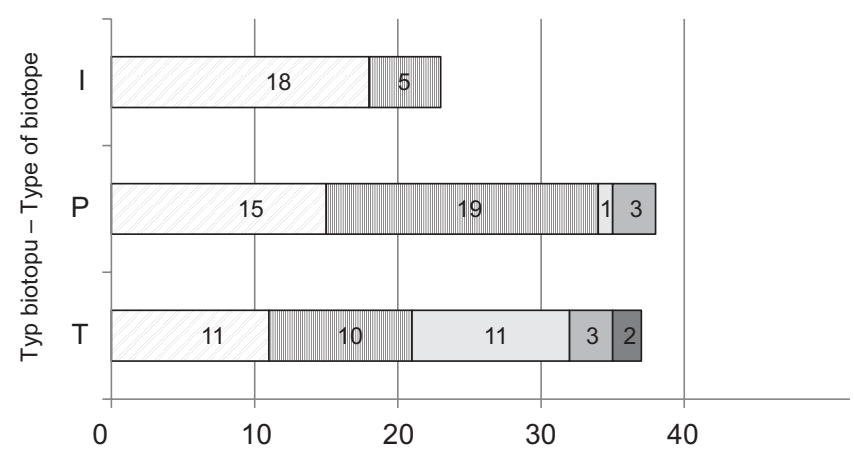

B

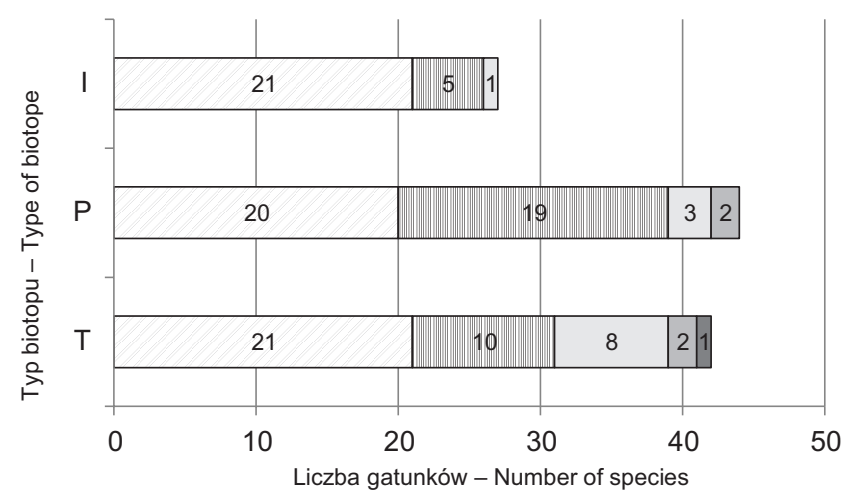

$\square$ sporadyczne

๒ b. rzadkie

$\square$ rzadkie

$\square$ częste

$\square$ pospolite sporadic very rare rare common very common

Ryc. 8. Częstość występowania archeofitów (A) i kenofitów (B) w wyróżnionych typach biotopów: T - torowiska ścisłe, $\mathrm{P}$ - przytorza, I - tereny infrastruktury

Fig. 8. Occurrence of archaeophytes (A) and kenophytes (B) in selected types of biotopes: $\mathrm{T}-$ tram tracks, $\mathrm{P}-$ tracksides, I - infrastructure 
Zjawisko rozprzestrzeniania się gatunków obcego pochodzenia (szczególnie inwazyjnych) wzdłuż linii tramwajowych ze względu na zagrożenie dla rodzimej różnorodności flory, a równocześnie nieliczne dane literaturowe na ten temat, wymaga dalszych badań

Podziękowania. Serdecznie dziękujemy Dyrekcji Spółki Akcyjnej Tramwaje Śląskie SA za wyrażenie zgody na przeprowadzenie badań na terenach tramwajowych konurbacji śląskiej oraz anonimowym Recenzentom za cenne uwagi do manuskryptu.

\section{LITERATURA}

BRANDES D. 2005. Die Flora der Stadtbahn Braunschweig. http://www.opus.tu-bs.de/opus/volltexte/2005/669 (dostęp: 31.03.2014).

BudneR W. 2008. Procesy metropolizacji i rozwoju metropolii w Polsce. - Acta Scientarum Polonorum Administratio Locorum 7(1): 5-16.

Czauderna T. 2004. Konstrukcje Torów Tramwajowych. - Technika Transportu Szynowego 9: 56-59.

Giedych R., SzulczewsKa B. \& MaKsymiuk G. 2012. Problemy zarządzania zieloną infrastrukturą miasta na przykładzie Warszawy. - Problemy Ekologii Krajobrazu 33: 203-213.

Hansen M. J. \& Clevenerg A. P. 2005. The influence of disturbance and habitat on the presence of nonnative plant species along transport corridors. - Biological Conservation 125: 249-259.

KLERA M. 2008. Wpływ siedliska na zróżnicowanie szaty roślinnej torowisk i przytorzy tramwajowych Szczecina w warunkach antropopresji. Mskr. pracy doktorskiej, Katedra Dendrologii i Kształtowania Terenów Zieleni, Zachodniopomorski Uniwersytet Technologiczny, Szczecin.

KLERA M. \& BACIECZKo W. 2013. Specyfika flory infrastruktury tramwajowej Szczecina jako przejaw skrajnej synantropizacji siedliska. - Folia Pomeranae Universitatis Technologiae Stetinensis, Agricultura, Alimentaria, Piscaria et Zootechnica 302(25): 59-94.

KondRACKI J. 1998. Geografia regionalna Polski. s. 440. Polskie Wydawnictwo Naukowe, Warszawa.

Mirek Z., PięKoś-Mirkowa H., ZaJĄC A. \& ZAJąC M. 2002. Flowering plants and pteridophytes of Poland. A checklist. - W: Z. MireK (red.), Biodiversity of Poland. 1, s. 442. W. Szafer Institute of Botany, Polish Academy of Sciences, Kraków.

OlEKSIEWICZ W. \& KRAŚKIEWICZ C. 2013. Rozwój konstrukcji i układu geometrycznego torowisk tramwajowych, jako istotny element postępu w miejskim transporcie szynowym. - Zeszyty Naukowo-Techniczne Stowarzyszenia Inżynierów i Techników Komunikacji w Krakowie. Materiały Konferencyjne 3(102): 307-324.

Plan Zagospodarowania Przestrzennego Województwa Śląskiego. 2004. http://www.slaskie.pl/ przest_plan/pzpws.pdf (dostęp: 11.02.2018).

Priemus H. \& ZonNeveld W. 2003. What are corridors and what are the issue? Introduction to special issue: the governance of corridors. - Journal of Transport Geography 11: 167-177.

Rutkovska S., PučKaA I., Evarts-Bundersb P. \& Paiderec J. 2013. The role of railway lines in the distribution of alien plant species in the territory of Daugavpils City (Latvia). - Estonian Journal of Ecology 62: 212-225.

Solon J., Borzyszkowski J., BidŁasik M., Richling A., Badora K., Balon J., Brzezińska-Wójcik T., Chabudziński Ł., Dobrowolski R., Grzegorczyk I., JodŁowski M., Kistowski M., Kot R., Krąż P., Lechnio J., Macias A., Majchrowska A., Malinowska E., Migoń P., Myga-Piątek U., Nita J., Papińska E., Rodzik J., StrzyŻ M., TerpiŁowski S. \& Ziaja W. 2018. Physico-geographical mesoregions of Poland: verification and adjustment of boundaries on the basis of contemporary spatial data. - Geographia Polonica 91(2): 143-170. 
Stoeck T. 2012. Priorytety utrzymania i rozwoju komunikacji tramwajowej na przykładzie Elbląga. - Autobusy 5: 445-450.

SUDNIK-WóJCIKOWSKA B. 1998. Czasowe i przestrzenne aspekty procesu synantropizacji flory na przykładzie wybranych miast Europy Środkowej. s. 167. Wydawnictwa Uniwersytetu Warszawskiego, Warszawa.

SUDNIK-WóJcIKowsKa B. 2002. Flora miasta - chaos i przypadek czy prawidłowości w różnorodności. - Kosmos 51(2): 213-219.

SudNiK-WóJcikowska B. \& Galera H. 2005. Floristic differences in some anthropogenic habitats in Warsaw. - Annales Botanici Fennici 42: 185-193.

Sudnik-Wójcikowska B. \& Galera H. 2011. Warsaw. - W: J. G. Kelcey \& N. Müller (red.), Plants and Habitats in European Cities, s. 499-545. Springer, New York.

Tokarska-Guzik B., Dajdok Z., Zając A., Urbisz A., Danielewicz W. \& HoŁdyński C. 2012. Rośliny obcego pochodzenia w Polsce ze szczególnym uwzględnieniem gatunków inwazyjnych. s.197. Generalna Dyrekcja Ochrony Środowiska, Warszawa.

TRAmwaJe ŚląSKIE S.A. Infrastruktura techniczna. Stan na 29 maja 2018. https://www.tram-silesia.pl/ www/index.php/tabor/infra/ (dostęp: 11.12.2019).

Ustrnul Z., Limanówka D., Biernacik D., Czekiereda D. \& Cebulak E. 2015. Biuletyn monitoringu klimatu polski rok 2015. http://www.imgw.pl/images/stories/biuletyn_monitoringu/2015/rok2015.pdf (dostęp: 22.06.2018).

URBISZ A. 2019. Nowe stanowisko Euphorbia maculata (Euphorbiaceae) w Polsce. - Fragmenta Floristica et Geobotanica Polonica 26(1): 173-176.

WAGNER I., KraUZe K. \& ZaLewsKi M. 2013. Błękitne aspekty zielonej infrastruktury. - Zrównoważony Rozwój - Zastosowania 4: 145-155.

WeINER J. 2003. Życie i ewolucja biosfery. Podręcznik Ekologii Ogólnej. Wydawnictwo Naukowe PWN, Warszawa.

WiŁkomirski B., Galera H., Sudnik-Wójcikowska B., Staszewski T. \& Malawska M. 2012. Railway tracks - habitat conditions, contamination, floristic settlement - a review. - Environmental and Natural Resources Research 1: 86-95.

WojTASZEK M. 2015. Inwestycje w górnośląską sieć tramwajową. - Technika Transportu Szynowego 22(6): 15-18.

Ziernicka-WoJTASZeK A. \& ZaWora T. 2009. Zróżnicowanie pluwiotermiczne polski w świetle współczesnych zmian klimatu. - Acta Agrophysica 12(1): 289-297.

\section{SUMMARY}

In many cities, areas covered by the streetcar system provide specific types of habitats. Vascular flora associated with streetcar lines have been poorly investigated. Reports on the floras and vegetation of these areas are limited (SUDNIK-WóJCIKOWSKA \& GALERA 2005, 2011; KLERA 2008; KLERA \& BACIECZKo 2013). This paper presents a list of alien plant species recorded in areas covered by the tram system in the Silesian conurbation, and describes the habitat preferences of the plants.

The research was done in the Silesian conurbation, located in the central and eastern parts of Silesia Province (S Poland). The Silesian conurbation is formed by towns surrounding Katowice, the capital of the province (BUDNER 2008), and includes 14 towns. The tram network and the infrastructure necessary for its operation is located in 13 towns: Katowice, Bytom, Chorzów, Świętochłowice, Gliwice, Zabrze, Ruda Śląska, Siemianowice Śląskie, Mysłowice, Sosnowiec, Dąbrowa Górnicza, Czeladź and Będzin (WOJTASZEK 2015). 
Areas along the streetcar lines differ in terms of traffic intensity, degree of development, and substrate. For this reason, the research was done within three different biotopes: tram tracks (T), areas along tram tracks $(\mathrm{P})$ and areas under infrastructure (I). The tram track biotopes covered the land between the tracks, and in the case of double tracks, also areas between the tracks and a $0.5 \mathrm{~m}$ wide strip of land along the outer track (Fig. 1). This habitat is characterized by a strong impact of tram traffic, strong insolation, and poor soil on top of the crushed stone layer (SUDNIK-WÓJCIKOWSKA \& GALERA 2005; KLERA 2008). Habitats along the tram tracks were defined as strips of land along the tracks, located 0.5 to $2.5 \mathrm{~m}$ from the outer track. Areas under infrastructure were usually 2.5-5-meter-wide zones around the tracksides in places such as traffic islands, tram traffic nodes, depots, tram stops and areas directly adjacent to them.

Field studies were conducted in 2014-2019. Floristic surveys for all three types of habitats were carried out primarily on tracks not located within roads, because plants were recorded only in such locations. In total, $122 \mathrm{~km}$ of track (single and/or double) were covered by the study. Tracks out of service and not used for transportation were not investigated. Within the whole conurbation we established 122 1-km-long transects and regarded them as the basic research units (Fig. 2, Tab. 1). A floristic list was prepared. The list of plant species is alphabetized and includes all alien plant species, even escapees from cultivation. The following information was presented for every taxon:

1. Latin name of plant species (MIREK et al. 2002);

2. Geographical and historical group, according to the system and criteria proposed by TOKARSKAGuZIK et al. (2012);

3. Biotope in which the species was recorded;

4. Frequency of plant species in each biotope, based on the frequency of the species in the explored transects;

5. List of transects - number and code(s) of transects where the species was recorded; and

6. Estimated number of specimens and/or their distribution (e.g. single plants, clusters, large patches).

We recorded 99 alien plant species in tram track areas in the Silesian conurbation, including 45 archaeophytes, 49 kenophytes and 5 diaphytes. The flora of the investigated tracks includes 33 invasive plant species. The number of plant species was highest in areas along tram tracks (86) and on tram tracks (81), and lowest in areas covered by infrastructure (51).

The study revealed that areas under tram tracks in cities can serve as corridors for the migration of alien plant species, including invasive species such as Acer negundo, Ailanthus altissima, Fraxinus pennsylvanica, Solidago canadensis and Reynoutria japonica, as well as plants associated with urban heat islands, such as Bromus sterilis, Diplotaxis muralis, Hordeum murinum and Eragrostis minor. They can also provide habitats suitable for Euphorbia maculata and other species.

Wptynęto: 13.03.2020 r.; przyjęto do druku: 15.07.2020 r. 